\title{
脳血管障害急性期の心電図所見
}

\begin{tabular}{|c|c|c|c|c|c|}
\hline \multicolumn{6}{|c|}{ 長崎大学医学部第二内科 } \\
\hline 久保 & 進 & 江良 & 修 & 田川 & 秀小 \\
\hline 福井 & 純 & 松本 & 保和 & 坂井 & \\
\hline 今村 & 俊之 & 古賀 & 秀隆 & 原 & \\
\hline
\end{tabular}

\section{ELECTROCARDIOGRAPHIC CHANGES IN 150 PATIENTS WITH} CEREBROVASCULAR ACCIDENTS

Susumu Kubo, MD, Osamu ERA, MD, Hideki Tagawa, MD, Jun FuKui, MD, Yasukazu Matsumoto, MD, Akinori SaKaI, MD, Toshiyuki Imamura, MD, Hidetaka Koga, MD, Kohei HaRA,MD

The Second Department of Internal Medicine, Nagasaki University School of Medicine Nobuharu OHE, MD

Department of Internal Medicine Yahata City Hospital, Kitakyushu, Fukuoka

概要 頭部CTおよび脑血管造影で診断が確定した150例の急性期脳血管障害患者につき，入院 時の心電图変化々揄查所見, 重症度, 病变部位なととの比較検討を行なつた。内訳は，くも膜 下出血 43 例（男 $17 ， 女 26$ ，平均年令 $50.2 才 ）$ 脳内出血 87 例（男 $63 ， 女 24$ ，平均年令 $54.0 才 ）$ 脳 梗塞20例（男15，女 5，平均年令56.3才）で，70才以上，明らかな心疾患の既往を有する例， 心房細動例などは除外した。各群ともに約 $80 \%$ に心電図異常がみられ，ST-T变化，QT時間延 長，左室肥大などの頻度が多からた，QT時間延長は，くも膜下出血では58\%にみられ，脳内出 血 (38\%)，脳梗塞 $(25 \%)$ 上り有意に高頻度であつた $(\mathbf{p}<0.05)$ ，生存群と死亡群の比較では， 死亡群に洞性頻脈 $(\mathrm{p}<0.01)$ ，ST-T变化 $(\mathrm{p}<0.1)$ を多く又とめ，不整脈の頻度名高かつたが， U波は逆に生存群に多くみられた $(\mathrm{p}<0.01)$ 。李た意識障害の程度が強くなる汪ど洞性頻脈, 不整脈; 左室肥大の頻度が高かつた。脳内出血部位の比較では, 橋出血にST-T変化が有意に多 くみられ $(\mathrm{p}<0.1)$ ，視床出血ではQT時間延長が多い攧向がみられた，検查所見では，くも膜 下出血や重症例では白血球増加，高血糖などが高度にみられ，GOTやLDHの上昇は10４4\%に みられた。これら心電因変化の成因については諸説があるが，くも膜下出血では，脳血管の spasmとともに冠動脈のspasmがおこつている可能性が考劣られた。

\section{I. 緒 言}

脳血管障害急性期に種々の心電図変化が出現す

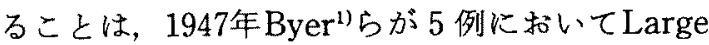
upright $\mathrm{T} と \mathrm{QT}$ 時間延長を報告して以来，広く知 られるようになつた. Surawiczは2), 高振幅の広い T波（"giant" T waves）を，脳血管障害時の特

昭和58年 4 月 2 日受稿]
徵的な所見として "CVA pattern" と表現したが その他種々の不整脈，QT時間延長，ST变化，U 波などが高頻度に出現すると報告している314)。こ れらの心電図変化の成因については動物実験など も含めて多数の研究があるが，未だ明確でないの が現状である。今回我々は，救命救急せンターに 入院した150名の脳血管障害患者の, 入院時の心電 図変化を，検査所見，障害部位，重症度，予後な 
Table 1. Patients with cerebrovascular accidents.

\begin{tabular}{|c|c|c|c|c|c|c|c|}
\hline & \multirow{2}{*}{$\begin{array}{l}\text { No.of } \\
\text { patients }\end{array}$} & \multicolumn{2}{|c|}{ Sex } & \multicolumn{2}{|c|}{ Age } & \multicolumn{2}{|c|}{ Hypertension $(8)^{*}$} \\
\hline & & & & range & $($ mean \pm SD) & Past history & On admission \\
\hline $\begin{array}{l}\text { Subarachnoid } \\
\text { hemorrhage }\end{array}$ & 43 & 17 & 26 & $17-67$ & $(50.2 \pm 10.9)$ & 30 & 51 \\
\hline Intracerebral hemorrhage & 87 & 63 & 24 & $28-69$ & $(54.0 \pm 9.0)$ & 61 & 90 \\
\hline Cerebral infarction & 20 & 15 & 5 & $33-68$ & $(56.3 \pm 8.9)$ & 60 & 75 \\
\hline
\end{tabular}

*Systolic blood pressure $>160 \mathrm{mmHg}$ and/or diastolic blood pressure $>95 \mathrm{mmHg}$

どと対比検討するとともに, これら心電図変化の 成因についての文献的考察む行なつたので，併せ て報告する。

\section{II. 対象と方法}

対象は，昭和53年10月から昭和56年 9 月末での 3 年間に, 北九州市立八幡病院救命救急センター に入院した脳血管障害患者のうち，(1) 頭部CT括 よび脳血管造影で確定㟝断がついたもの，(2) 発 症後48時間以内に入院し，末治療のもの，（3）虚 血性心疾患などの明らかな心疾患の既往や，脳血 管障害の既往を有しないるの，(4) 70才以下の 4 条件をみたしたもの150例を選んた。をた，入院時 心房細動であつた例む，その発生時期が不明であ ることや心電図への影響を考慮し，今回は除外し た.

その内訳は, Table 1に示したごとく,くも膜下 出血43例, 脑内出血87例, 脳梗塞20例で, 脳梗塞 の症例数が少なかつた理由は心房細動例や高令者 を除外したためであつた。性別，年令についてみ ると，くす膜下出血では他の 2 群上り女性が多く， 若干若い年令層のものが多くを占めた．高血圧の 有無については，既往歴と入院時の頻度を調べた が，両者ともに脳内出血や脳梗塞の方がくも膜下 出血よりも高頻度を占めた. Table 2に頭部CTお よび脳血管造影で確認された病变部位を示した が，先人の報告されている頻度と殆ど変りなかつ た，入院後直ちに標準12誘導心電図を記録すると 共に，一般検血，電解質，血糖，GOT, GPT, LDH を測定した，心電图の判読は診断名を伏せて行な い, QT時間はBazettの補正式QTc $=\mathrm{QT} / \sqrt{\mathrm{RR}}$ 用いてQTcを計算して，0.45秒以上をQT時間延 長とした。U波は脳部誘導で明らかに認められる
Table 2. Site of lesions.

\begin{tabular}{|c|c|}
\hline Subarachnoid hemorrhage & $\ldots+\ldots-n$ cases \\
\hline A-com & $13(30.38)$ \\
\hline I $\mathrm{C}$ & $4(7.3)$ \\
\hline $\mathrm{IC}-\mathrm{PC}$ & $7(16.3)$ \\
\hline $\mathrm{MCA}$ & $10(23.3)$ \\
\hline$A C A$ & $1(2,3)$ \\
\hline AVM & $1(2.3)$ \\
\hline Multiple & $7(16.3)$ \\
\hline Intracerebral hemorrhage & - 87 cases \\
\hline Thalamus & $19(21.8 \%)$ \\
\hline Putamen & $43(49.4)$ \\
\hline Thalamus + Putamen & $4(4.6)$ \\
\hline Subcortex & $6(6.8)$ \\
\hline Pons & $14(16.1)$ \\
\hline Cerebellum & $1(1.1)$ \\
\hline Cerebral infarction & n cases \\
\hline I $\mathrm{C}$ & $2\left(10 \frac{8}{8}\right)$ \\
\hline MCA & $16(80)$ \\
\hline PCA & $2(10)$ \\
\hline \multicolumn{2}{|c|}{$\begin{array}{l}\text { A-com: Anterior communicating artery } \\
\text { IC: Internal carotid artery } \\
\text { PC: Posterior communicating artery } \\
\text { MCA: Middle cerebral artery } \\
\text { ACA: Anterior cerebral artery } \\
\text { PCA: Posterior cerebral artery } \\
\text { AVM: Arterio-menous - malformation }\end{array}$} \\
\hline
\end{tabular}

ものを陽性とした。これらの心電図変化を, 病変 部位別に血液生化学的検查成績之, 各疾患群別に 比較検討した。

\section{III. 結 果}

\section{1）血液生化学的検查所見}

その成績をTable $3 に$ 示した。 くも膜下出血群 では，白血球増加，低K血症，高血糖を，いずれ も約 $75 \%$ と脳内出血群や脳梗塞群よりも有意に高 頻度に認めた．GOTやLDHの上昇はくも膜下出 血群や脳内出血群で10４4\%に認められたが, 
Table 3. Incidence of abnormal laboratory findings in patients with cerebrovascular accidents.

\begin{tabular}{|c|c|c|c|}
\hline & $\begin{array}{l}\text { Subarachnoid } \\
\text { hemorrhage }\end{array}$ & $\begin{array}{l}\text { Intracerebral } \\
\text { hemor rhaqe }\end{array}$ & $\begin{array}{l}\text { Cerebral } \\
\text { infarction }\end{array}$ \\
\hline$W B C>9000 / \mathrm{mm}^{3}$ & $35 / 42(83 \%)$ & $38 / 86(448)^{\circ}$ & $8 / 18(448)^{*}$ \\
\hline$K<3.5 \mathrm{mEq} / \mathrm{L}$ & $12 / 16(75) *$ & $29 / 84(35)$ * & $2 / 18(11)^{\circ}$ \\
\hline Blood sugar $>140 \mathrm{mg} / \mathrm{d}$ & $17 / 23(74)$ * & $29 / 84(35) *$ & $2 / 18(11)^{\circ}$ \\
\hline GOT > 40 Karmen & $4 / 41(10)$ & $14 / 73(19)$ & 0 \\
\hline GPT > 35 Karmen & 0 & $1 / 73(1)$ & 0 \\
\hline LDH $>400$ Wroblewski & $4 / 18(22)$ & $11 / 45(44)$ & $4 / 14(29)$ \\
\hline
\end{tabular}

GPTの上昇は殆どみられなかつた. 生存群と死亡 群を比較すると, 脳内出血群で, 白血球数（生存 群 $8700 \pm 3800 / \mathrm{mm}^{3}$, 死亡群 $11000 \pm 4800 / \mathrm{mm}^{3}$, $\mathrm{p}<0.025$ ), 血糖（生存群 $127 \pm 25 \mathrm{mg} / \mathrm{dl}$ 死亡群 $196 \pm 83 \mathrm{mg} / \mathrm{dl}, \mathrm{p}<0.005)$ ともに, 死亡群で高度 な異常を認め，この傾向はくも膜下出血群でも認 められた。

\section{2）入院時の心電図所見}

心電図異常の出現率は，Table 4に示したごと く，3群ともに約 $80 \%$ と高率に認められた。 各群ともST-T変化, QT時間延長, 左室肥大, U 波などの出現頻度が高く，先人の報告とほぼ同様 の傾向が認められた３群間で統計的に有意差を みとめたのは，QT時間の延長のみで，くも膜下出 血群で $58 \%$ と明らかに高頻度を占めた（p< 0.05)。をたくも膜下出血群では, ST上昇や冠性 T波，巨大T波を 7 ～9\%に認めたが，脳内出血 群では, ST上昇 $5 \%$, 冠性T波 2\%, 巨大T波 $0 \%$ と低頻度であり，脳梗塞群では 3 者とも認められ なかつたまた，心筋梗塞様のST上昇はくも膜下 出血群にのみ認めた。入院時の1枚の心電図のみ から不整脈の種類や頻度を検討することには問題

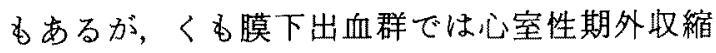
（VPC）を認めたものが 3 例あり，5ち 1 例に short runを認めた.

\section{3）重症度別による心電図所見}

Fig 1はく膜下出血群之脳内出血群に括い $て$ ，生存例と死亡例の心電図所見を比較したすの
Table 4. ECG findings in 150 patients with cerebrovascular accidents on admission.

\begin{tabular}{|c|c|c|c|}
\hline & $\begin{array}{l}\text { Subarachnoid } \\
\text { hemorrhage }\end{array}$ & $\begin{array}{l}\text { Intracerebra! } \\
\text { hemorrhage }\end{array}$ & $\begin{array}{l}\text { Cerebral } \\
\text { infarction }\end{array}$ \\
\hline No. of patients & 43 & 87 & 20 \\
\hline Abnormal ECG & $35(81 \%)$ & $68(788)$ & $16\left(80 \frac{0}{6}\right)$ \\
\hline Sinus tachycardia & $4(9)$ & $11(13)$ & $2(10)$ \\
\hline Sinus bradycardia & $5(12)$ & $6(7)$ & $3(15)$ \\
\hline Axis deviation & $1(2)$ & $9(10)$ & $I(5)$ \\
\hline VPC & $3(7)$ & $3(3)$ & 0 \\
\hline$A P C$ & $1(2)$ & $1(1)$ & 0 \\
\hline AV block $\left(11^{\circ}\right)$ & 0 & $1(1)$ & 0 \\
\hline $\begin{array}{l}\mathrm{LVH} \\
\left(S v_{j}+R V_{5}>3.5 \mathrm{mV}\right)\end{array}$ & $15(35)$ & $32(37)$ & $5(25)$ \\
\hline$S T-T$ change & $22(51)$ & $37(43)$ & $10(50)$ \\
\hline ST-depression & $12(28)$ & $28(32)$ & $10(50)$ \\
\hline ST-elevation & $4(9)$ & $4(5)$ & 0 \\
\hline Coronary $T$ & $3(7)$ & $2(2)$ & 0 \\
\hline Tall T & $4(9)$ & $0(0)$ & 0 \\
\hline Prolonged QTC & $25(58) *$ & $33(38)$ & $5(25)$ \\
\hline U wave & $26(61)$ & $56(64)$ & $13(65)$ \\
\hline Abnormal $Q$ & $3(7)$ & $4(5)$ & 0 \\
\hline
\end{tabular}

${ }^{*} P<0.05$ difference from other two groups

であるが，〈も膜下出血群では，洞性頻脈，ST-T 変化が死亡例で有意に多く認められ $(\mathrm{p}<0.01)$ ， 逆にU波は生存群に有意に多く認められた（ $\mathrm{p}<$ 0.01)。QT時間の延長や左室肥大は死亡例にやや 多かつたが，有意差はなかつた，脳内出血群でも 添同様の傾向を示した. ST-T変化のうち，ST の上昇を認めた，〈も膜下出血群での 4 例中 3 例 および, 脳内出血群での 4 例中 3 例は死亡して和 り, ST上昇を認めれば予後は不良なことを推測さ せた。 


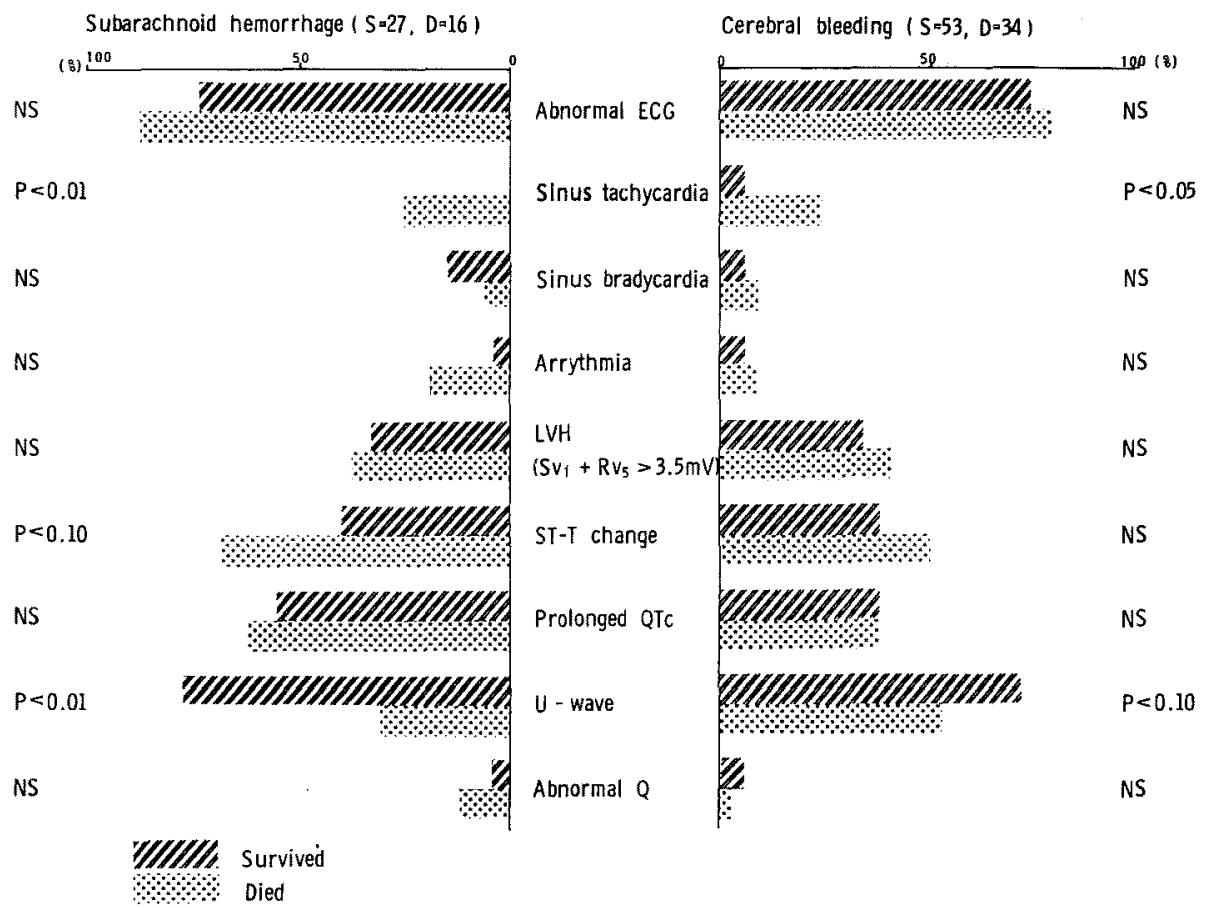

Fig 1. Comparison between survived (S) and died (D) patients with subarachnoid hemorrhage and intracerebral hemorrhage.

\section{4）意識障害の程度と心電図所見}

Fig 2は，入院時の意識障害の程度による変化 の出現頻度を示したものである. 意識障害の分類 は3-3-9度方式を用いた。すべての心電図異常 の出現頻度には差を認めなかつたが，洞性頻脈，

不整脈, 左室肥大は意識障害の強い群に有意に多 く認め，一方，洞性徐脈，U波は意識障害の軽い 群に多く認めた.

5）脳内出血部位おょび脳室穿破の有無と心電 図所見

頭部CTにより確認された視床出血19例, 被殼出 血43例，橋出血13例につき，心電図の变化を検討 した (Table 5).一般的には視床下部病変がある 際には心電図異常を認めることが多いとされてい るが，今回の検討では 3 群間に有意差をみとめた のはST-Tの変化のみで, 橋出血に多く認められ た $(\mathrm{p}<0.1)$. 統計学的に有意差ではなかつたが, 左室肥大は被殼出血に多く，QT時間延長は視床 出血に多くみられた。

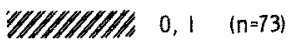

II, III (n-49)

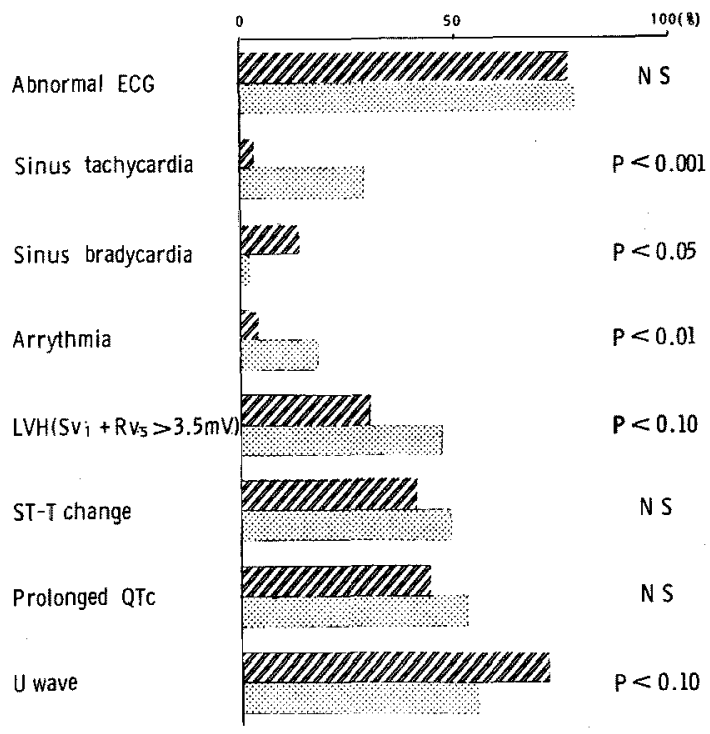

Fig 2. Incidence of ECG changes and consciousness level (3-3-9) on admission in patients with cerebrovascular accidents. 
Table 5. ECG and laboratory findings in patients with intracerebral hemorrhage.

\begin{tabular}{lccl}
\hline & Thalamus & Putamen & Pons \\
\hline No. of pateints & 19 & 43 & 13 \\
\hline Electrocardiogram & & & \\
Abnormal ECG & $15(79 \%)$ & $34(79 \%)$ & $10(77 \%)$ \\
Sinus tachycardia & $1(5)$ & $7(16)$ & $2(15)$ \\
Sinus bradycardia & 0 & $5(12)$ & $1(8)$ \\
Arrythmia & 0 & $4(9)$ & 0 \\
LVH** & $5(26)$ & $20(47)$ & $4(31)$ \\
ST-T change & $6(32) *$ & $19(44)$ & $8(62) *$ \\
Prolonged QTC & $9(47)$ & $15(35)$ & $5(39)$ \\
U wave & $15(79)$ & $27(63)$ & $8(62)$ \\
Abnormal Q & 0 & $2(5)$ & $1(8)$ \\
\hline
\end{tabular}

* Difference $P<0.1$

** Sv $v_{1}+R v_{5}>3.5 \mathrm{mV}$

Table 6. Comparison between ventricular ruptured and non-ruptured patients with intracerebral hemorrhage.

\begin{tabular}{lccc}
\hline & Ruptured & Non-ruptured \\
\hline No. of patients & 32 & 55 \\
\hline Electrocardiogram & & & NS \\
Abnormal ECG & $24(75 \%)$ & $42(76 \%)$ & P $<0.10$ \\
Sinus tachycardia & $6(19)$ & $5(9)$ & NS \\
Sinus bradycardia & $0(0)$ & $5(11)$ & NS \\
Arrythmia & $3(9)$ & $3(6)$ & NS \\
LVH** & $12(38)$ & $20(36)$ & P $<0.05$ \\
ST-T change & $9(28)$ & $28(51)$ & NS \\
Prolonged QTC & $12(38)$ & $21(38)$ & NS \\
U wave & $20(63)$ & $36(65)$ & NS \\
Abnormal Q & $1(3)$ & $3(6)$ &
\end{tabular}

* Chi-squaure

$\star \star S v_{1}+R v_{5}>3.5 m V$

脳室穿破の有無による比較では, Table 6に示 したように，穿破群に洞性頻脈が有意に多く( $\mathrm{p}<$ $0.10), \mathrm{ST}$-Tの変化は非穿破群に有意に多くみと めた $(\mathrm{p}<0.05)$.

\section{IV. 症 例}

患者：TS，65才，家婦。

主訴：意識障害.

既往歴：高血圧 ( 5 年前より降圧剤服用中).

家族歴：特記事項なし。

現病歴： 5 年前より高血圧で治療中であつた が, 昭和56年 5 月 1 日夕食後, 風呂場で意識消失
しているところを発見され，脳血管障害の疑いで 救急入院となつた（発症後約 2 時間）.

入院時現症：意識レベルI-3（3-3-9 度方 式，血王 $106 / 78 \mathrm{mmHg}$ ，脈拍 $104 /$ 分で整，呼吸数 $30 /$ 分，体温 $36^{\circ} \mathrm{C}$. 瞳孔は左右不同なく，対光反射 は，正常．貞血や黄疸はなく，胸腹部に異常を認 めなかつた，神経学的には，項部硬直があり，軽 度の左半身不全麻㿁をみとめたが，病的反射は認 めなかつた。

入院時検查成績：赤血球数 372 万 $/ \mathrm{mm}^{3}$, 几モ グロビン $10.7 \mathrm{~g} / \mathrm{dl}$, ヘマトクリット $33 \%$, 白血球数 $11900 / \mathrm{mm}^{3}$ (St 2, Seg 90, Mo 1, Ly 7), 血小板数

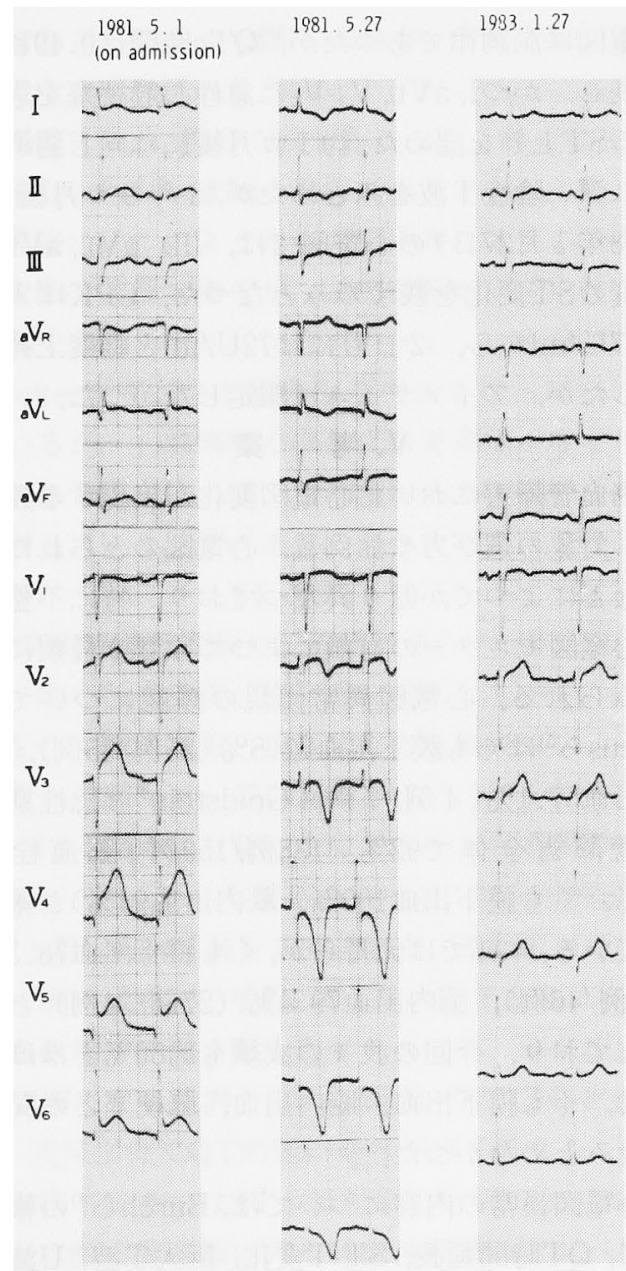

Fig 3. Electrocardiogram. TS, 65y, F. 
29.3 万 $/ \mathrm{mm}^{3}$ ．検尿では，蛋白 $(H)$ ，糖 (一). 生 化学的には, 血清蛋白 $7.1 \mathrm{~g} / \mathrm{dl}$, GOT 40 Karmen, GPT 12Karmen, LDH 307 Wrobreski, CPK 37 $\mathrm{U} / \mathrm{ml}, \quad \mathrm{BUN} 15 \mathrm{mg} / \mathrm{dl}, \mathrm{Cr} 1.1 \mathrm{mg} / \mathrm{dl}, \mathrm{Na}$ $140 \mathrm{mEq} / l, \quad \mathrm{~K} .3 .1 \mathrm{mEq} / l, \quad \mathrm{Cl} \quad 99 \mathrm{mEq} / l$, BS $176 \mathrm{mg} / \mathrm{d} 1$ の成續であつた。

入院後経過： 頭部CTではシルビウス溝やそ の他の各脳槽にhigh densityを認め, くも膜下出 血と診断した。 4-vessel studyの結果, 左中大脳動 脈の動脈瘤破裂之, 左後下小脳動脈にも動脈瘤を 又とめた。 入院第 2 日目に脳外科にて手術を施行 し，その後の経過は順調である。

心電図の経時的変化： 本症例の経時的な心電 図の変化をFig 3に示した。 入院值後にとられた 心電図は洞調律であつたが，QTc時間は0.49秒と 延長し，かつ $\mathrm{I}, \mathrm{aVL}, \mathrm{V}_{3}-\mathrm{V}_{6}$ に急性心筋梗塞を思わ せるST上昇を認めた。約 1 力月後には同じ誘導部 位に深い陰性 T波をみぬたが，1年 9 力月後(昭 和58年 1 月27日) の心電図では，III， $\mathrm{aVL}, \mathrm{aVFK}$ 軽度のST変化を残すのみとなつた。CPK入院 時 $37 \mathrm{U} / \mathrm{ml}$ から，2 日目には $72 \mathrm{U} / \mathrm{ml}$ と軽度上昇を 示したが，アイソザイムは測定しなかつた。

\section{V.考案}

脳血管障害に技いて心電図変化が出現する頻度 は，対象の選び方や症例数，心電図のとられた時 期などによつてかなり異なつて打り，特に不整脈 は心電図モニタ一の有無によつて頻度や種類に差 が文られる。心電圀異常出現の頻度について, Kreusら5)はくも膜下出血71.5\%(25例/35例)，脳 内出血 $57.1 \%$ ( 4 例/ 7 例), Goldstein ${ }^{61}$ は急性期脑 血管障害全体で92\%（138例/150例一脳血栓症 $86 \%$ ，〈子膜下出血 $100 \%$, 脳内出血 $94 \%$ ) と報告 している.本邦では元持らが，〈子膜下出血78.3\% (36例/46例), 脳内出血79.4\%(27例/34例） と報 告しており，今回の我々の成績も約 $80 \%$ と注涪同 様で, くも膜下出血, 脳内出血, 脳梗塞との間に 差をみ上めなかつた。

心電図異常の内容については, Burch ら3)の報告 以来, QT時間延長, ST-T変化, 巨大T波, U波の 出現, 種々の不整脈があげられているが, 今回の
成績もほぼ同様の成績を得た。くも膜下出血群で はQT時間延長は $58 \%$ に認められ，脳内出血群 （38\%）や脳梗塞群（25\%）に比ぺて明らかに高頻 度であつたが, Goldstein ${ }^{6}$ もQT時間延長の頻度 を, く子膜下出血 $71 \%$, 脳内出血 $50 \%$, 脳血栓症 $37 \%$ と報告していて，QT時間延長はくも膜下出 血に特徽的な所見であると考えられた。あた、く も膜下出血ではST上昇や冠性 T波，巨大T波を多 くみとめる㑯向があつた。

今回は心電図モニターを行なわなかつたため, 不整脈については詳細に論じることはできない が，重症例では心室期外收縮や洞性不整脈をみと めた例が多く, 死亡した 1 例にVPCのshort runが

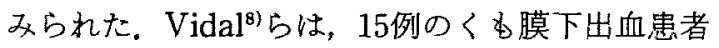
で，入院時より最低 5 日間の心電図モニターによ る検查を行なつているが，全例に何らかの不整脈 を認め，その20\%には生命を括びやかす上らな危 険な不整脈をみとめ，しかるQT時間の延長を伴 つた例が多かつたと述べている。本邦でも吉岡 ら 9 により，くも膜下出血に合併した心室細動の 1 例が報告されており，急性期にはその管理に十 分注意すべきことと思われる。

脳血管障害の重症度によつて, 心電図異常の種 類や頻度に差があるか否かについての報告は少な い. 元持ら》はHunt \& Konsikのgrading と心電図 変化の関係を検討し, Grade 1で61.9\%, Grade 2 で92.9\%, Grade 3，4では100\%と，重症になるほ ど心電図变化の頻度が高かつたと述べている。 我々は，生存例と死亡例和よび意識障害の程度に よる比較を行なつたが，死亡例や意識障害が強か つた群では, 洞性頻脈や不整脈, ST-Tの变化の出 現頻度が有意に高かつた。 またこれらの群では， 白血球増加中高血糖を認めた例が多く, 交感神経 系やカテコラミンの関与が示唆された。

心電図上の異常所見の出現頻度や種類が脳の障 害部位によつて差があるかどうかは，心電図変化 の成因とも関係して，興味深い問題である。これ については，動物では種々の検討がなされている ものの，臨床例での報告は少ない，今回の我々の 検討では, 脳幹部出血ではST-T変化が多く, 視床 
出血ではQT時間延長の頻度が多い傾向がみられ

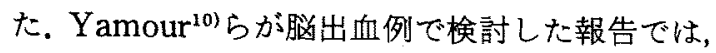
前頭葉ではQT時間延長やT波の変化が多く，脳 幹部では非心原性肺水腫や心房細動の発生を伴亏 ことが多からた成績を得でり，前頭葉眼窝面の area 13 や Willis輪周辺の病变に伴 $5 心$ 電図变化 の原因は，前頭葉眼窝面から発生する交感神経系 や副交感神経系のtoneの変化が星状神経節を介し て心葴に㧁劣られるためとしている。

脳血管障害に伴う心電㘠变化の成因について は，低 $\mathrm{K}$ 血症などの電解質異常，高血王症，虚血 性心疾患などが考えられた時期もあったが，現在 では脳血管障害に伴つて抗こる自律神経系のアン バランスによるとする説が有力である.これにす， neuronal説と血中カテコラミンなどによる humoral説とがある ${ }^{11}$. 今回の検討でも，心電図異 常の頻度はKやCaとはあまり相関せず，むしろ白 血球増加や高血糖と相関する傾向がみられた。 カ テコラミンと心電図変化の関保については, 本邦 では, 友松ら ${ }^{12)}$ 研究があつて, 尿中カテュラミン の推移から，カテコラミンの増加が心電図变化の 原因となるものと推論している。新たCruickshank $ら^{13)}$ は，40例のく子膜下出血患者について 尿中カテコラミンや血中コルテゾル，心電図の変 化を調ベ，くも膜下出血によつて生じた視床下部 の病変によつて尿中カテコラミンや血中コルチゾ ルの上昇がおこり，心電図に変化をるたらすと結 論している.

ところで，このような自律神経系のアンバラン スやカテコラミンの増加が，どのような機序によ つておこるかについては多数の動物実験がなされ ている(10)が，一般的には視床下部病変に基づくも のと考兄られている(14).Doshiら ${ }^{15)}$ は，〈む膜下出 血で死亡した12例について視床下部と心筋を組織 学的に調べ，〈も膜下出血以外の頭蓋内病変で死 亡した 6 例と対比している. その結果，くも膜下 出血で死亡した群にのみ視床下部と心筋の両方に 病変をみとめ, 視床下部の病変は両側性のびまん 性で，主に脳室周囲に認め，小血管周囲の出血や 周囲組織の浮腫が主な所見であつたが，心筇では 主として心内膜下に心筇壊死や細胞浸潤がfocal にみられたとしている。この結果からDoshi ${ }^{15)}$ は，視床下部を栄養する小血管の"spasm"が異常 な視床下部の興奮をおこし，増加したカテュラミ ンが心㬳障害を抏こすのであるうとしている。 Fabinyi ${ }^{16)}$ ，〈も膜下出血で脳血管造影上 "spasm"を認めた例では心電図変化が多く，しか も心筇由来のMB-CKの上昇を認める例が多かつ たと報告し，血管挛縮が交感神経系の刺激を惹起 し心筋に障害を与兄ると述べている，彼らは冠動 脈の挛縮については触れていないが, 我々の症例 でもくも膜下出血では心筇梗塞類似のST上昇を 認めた例が多からたこと, 冠動脈挛縮の成因の一 つに自律神経系のアンバランスが考えられている ことなどから、くも膜下出血においては脳血管た けでなく冠動脈にも"stasm"が起こつている可能 性が考之られ，極めて興味あることと考劣られた。 今後な険討を重ねる必要があると思われる。

最後に,このよらな脳血管障害に伴う心葴の障 害を防ぐ方法であるが，彭物実験では自律神経遮 断薬であるレセルピンやアトロピン，さらには $\beta$ blockerなどがある程度有效であることが示され ているが，心筋障害の発生に血管挛縮が重要な因 子であると考えれば，この面からの治療法も今後 検討していく必要があると思われる。

\section{VI. 結 論}

150例の急性期脳血管障害患者(く子膜下出血 43 例，脳内出血87例，脳梗塞20例）について，心電 図変化，検查所見，重症度などを検討した。各群 ともに約 $80 \%$ に心電図異常をみとめ，QT時間延 長, ST-T変化, 左室肥大などの所見を高頻度に認 めたが，とくにくる膜下出血では，QT時間延長や $\mathrm{ST}$ 上昇，巨大T波を多く認めた。重症例や死亡例 では洞性頻脈や不整脈，ST-Tの变化を多く認め， 白血球増加や高血糖も高度であつた，脳内出血の 部位別による検討では，脳幹部でST.T変化が多 く, 視床出血にQT時間の延長が多くみられ，また くも膜下出血ではST上昇を示した例が多かつた。 最後に脳血管挛縮に伴う自律神経系のアンバラン スが予想されていることより，心筋障害の成因と 
して冠動脈挛縮の可能性も考えられることを述べ た.

\section{文献}

1) Byer $E$, et al: Electroncardiogram with large upright $\mathrm{T}$ waves and long Q-T invervals. Amer Heart J 33: 796, 1947.

2) Surawicz B: Electrocardiographic pattern of cerebrovascular accident. JAMA 197: 913, 1966.

3) Burch GE, et al: A new electrocardiographic pattern observed in cerebrovascular accidents. Circulation 9: 719, 1954

4) Wasserman F, et al: Electrocardiographic observations in patients with cerebrovascular accidents. Report of 12 cases. Amer J Med Sci 231 : 502, 1976.

5) Kreus $\mathrm{KE}$, et al: Electrocardiographic changes in cerebrovascular accidents. Acta Med Scand 185: 327, 1969.

6) Goldstein DS: The electrocardiogram in stroke: Relationship to pathophysiological type and comparison with prior tracings. Stroke $10: 253,1979$.

7) 元持雅男, 他：〈も膜下出血, 脳内出血に抢汀る 心電図变化，脑卒中 $3: 287 ， 1981$.

8) Vidal BE, et al: Cardiac arrythmias associated with subarachnoid hemorrhage: Prospective study. Neurosurgery $5: 675,1979$.

9）吉田忠義，乾 迪雄：〈子膜下出血に合併した心 室細動の 1 症例。日内会誌 $69: 97,1980$.

10) Yamour BJ, et al: Electrocardiographic changes in cerebrovascular hemorrhage. Amer Heart J 99 : 294, 1980.

11) Weidler DJ: Myocardial damage and cardiac arrythmias after intracranial hemorrhage. A critical review. Stroke $5: 759,1974$.

12）友松達弥，他：脳血管障碍の心電目々尿中カテ コール体の変化について. Jan Circ J $28: 905$, 1964.

13) Cruickshank JM, et al: Possible role of cathecholamines, corticosteroids, and potassium in production of electrocardiographic abnormalities associated with subarachnoid hemorrhage. Brit Heart J $36: 697,1974$.

14) Crompton MR: Hypothalamic lesions follow ing the rupture of cerebral aneurysms. Brain $86: 301,1963$.

15) Doshi $R$ and Neil-Dwyer G: Hypothalamic and myocardial lesions after subarachnoid hemorrhage. J Neurol Neurosurg Psychiat 40 : 821, 1977

16) Fabinyi $G$, et al: Myocardial creatine kinase isoenzyme in serum after subarachnoid hemor rhage. J Neurol Neurosurg Psychiat 40:818, 1977. 